J. Clin. Chem. Clin. Biochem.

Vol. 27, 1989, pp. 863-868

(C) 1989 Walter de Gruyter \& Co.

Berlin $\cdot$ New York

\title{
A Simple Immunoturbidimetric Method for IgG and Albumin Quantitation in Cerebrospinal Fluid and Serum
}

\author{
By D. Croci, A. Nespolo
}

Istituto Neurologico "C. Besta”, Milano, Italia

\section{A. Bosoni}

Laboratorio Analisi Chimica Clinica, Ospedale Civile Vimercate (Milano), Italia and

\section{G. Tarenghi}

Direzioni Scientifica Miles Italiana SpA, Divisione Diagnostici, Cavenago Brianza (Milano), Italia

(Received February 23/June 21, 1989)

Summary: We describe a simple immunoturbidimetric method for measuring both IgG and albumin in CSF and serum, which enables the calculation of CSF indices. For each protein, only one calibration curve is used for both CSF and serum samples. The assay protocol is simple and similar for both tests. Sensitivity and versatility of the method afford measurements over a very wide range of concentrations (approx. 0.007 to $94 \mathrm{~g} / \mathrm{l}$ for IgG and 0.06 to $92.40 \mathrm{~g} / 1$ for albumin). Precision studies (triplicates for 6 runs over 15 days) gave overall CVs: $\leq 2.9$ and $4.9 \%$ for IgG in CSF $(11.5 \mathrm{mg} / \mathrm{l})$ and serum $(10.28 \mathrm{~g} / \mathrm{l}) ; \leq 1.3$ and $1.1 \%$ for albumin in CSF (115 mg/l) and serum (76.89 g/l). Comparison studies showed good correlation with radial immunodiffusion ( $r \geq 0.995$ and 0.976 for IgG and albumin) and rate nephelometry ( $r \geq 0.967$ and 0.982 for IgG and albumin). Thus, the method under investigation proved to be reliable and appears to be particularly suitable for the routine work.

\section{Introduction}

Quantitative determination of immunoglobulin G (IgG) and albumin in cerebrospinal fluid (CSF) is an important diagnostic test in the study of inflammatory disorders of the central nervous system (CNS) $(1-3)$.

Elevation of these CSF proteins results from two mechanisms:

(a) "passive diffusion" as a consequence of the increased permeability of the blood-CSF barrier in the presence of high levels of plasma proteins;

(b) "intrathecal synthesis" of IgG by B lymphocytes within the liquor compartment.
The quantitative indices for estimating the intrathecal IgG production, i. e. Link's index

$$
\frac{\mathrm{IgG}_{\mathrm{CSF}}, \mathrm{mg} / \mathrm{dl} \times \text { albumin }_{\text {serum }}, \mathrm{g} / \mathrm{dl}}{\mathrm{IgG}_{\text {serum }}, \mathrm{g} / \mathrm{dl} \times \text { albumin }_{\mathrm{CSF}}, \mathrm{mg} / \mathrm{dl}}
$$

(2), Tourtellotte's formula (4), and Reiber's formula (5), all include a correction for permeability changes of the blood-CSF barrier, and they are calculated from the IgG and albumin values in both serum and CSF. Besides being accurate and precise, analytical methods for quantifying these proteins in such fluids should have wide measuring ranges, because of the variability of the protein levels in patients with various neurological diseases (albumin from 0.05 to $80 \mathrm{~g} / \mathrm{l}$ and $\operatorname{IgG}$ from 0.006 to $100 \mathrm{~g} / \mathrm{l}$, approximately). 
Liquid-phase immunochemical techniques, such as nephelometry and turbidimetry, are now preferred to radial immunodiffusion (RID) for their sensitivity, precision, and rapidity. Unlike nephelometry, turbidimetry does not require a dedicated instrumentation. In this study, we explored the ability of an immunoturbidimetric method (6) to perform IgG and albumin assays on CSF and serum samples from patients affected by various neurological disorders.

\section{Materials and Methods}

Immunoturbidimetric method

\section{Reagents}

We used the reagent kits for the quantitative determination of IgG and albumin (SERA-PAK ${ }^{\circledR}$ immuno kits) from Miles Italiana SpA, Diagnostics Division, Cavenago Brianza, Italy.

Each kit provides:

1) antibody reagent, consisting of specific antiserum appropriately diluted in buffer $(100 \mathrm{mmol} / 1$ borate at $\mathrm{pH} 8.0$ in the IgG kit; $50 \mathrm{mmol} / 1$ Tris at $\mathrm{pH} 7.0$ in the albumin kit) containing, per litre, $40 \mathrm{~g}$ of polyethylene glycol 6000 (PEG), $1 \mathrm{~g}$ of sodium azide, and $2 \mathrm{~g}$ of a nonionic surfactant. The reagent is stable for at least one year at $2-8^{\circ} \mathrm{C}$;

2) diluent, containing per litre $9 \mathrm{~g}$ of sodium chloride and $1 \mathrm{~g}$ of sodium azide at $\mathrm{pH} 7.0$; in the albumin kit, the diluent also contains $5 \mathrm{~g}$ of gelatin;

3) calibrator, whose protein assigned values are based on the College of American Pathologists U.S. Reference Preparations for Serum Proteins (7); the working calibrators are prepared by serially diluting this calibrator with diluent and are stable for at least 2 months at $2-8^{\circ} \mathrm{C}$.

A polyethylene glycol solution, containing all the antibody reagent components except the specific antiserum, is also provided.

\section{Assay procedures}

For both proteins, we were able to utilize the same calibration curve for CSF and serum, the only difference being the dilution of the sample according to the total protein content and the assignement of appropriate values to working calibrators. Tables 1 and 2 summarize the assay procedures and typical concentration values for working calibrators.

NHR (Normal-High Range) and VHR (Very High Range) procedures for quantifying IgG in CSF employ different sample volumes ( $50 \mu \mathrm{l}$ vs $5 \mu \mathrm{l}$, the latter being the assay volume of the calibration curve). Absorbances in the CSF assay using $50 \mu \mathrm{l}$ of sample were therefore multiplied by the appropriate correction factor (1.089) to take account of the different final reaction volume.

\section{Apparatus}

For immunoturbidimetric assays we used an Optimate ${ }^{\mathrm{TM}}$ fluorometer/photometer (Ames-Gilford) with semi-automated procedure, 21 -fold predilutions of serum specimens being carried out separately.

Calculation of the calibration plots and of sample concentrations were performed by the 4-parameter logistic model or a 3 rd order polynomial function using an IBM personal computer.

\section{Comparative methods}

We assayed IgG and albumin by:

(a) a radial immunodiffusion method (NOR-Partigen ${ }^{\circledR}$ plates from Behringwerke AG, Marburg, Lahn, F. R. G.), but using the SERA-PAK working calibrators for calibration, because of a discrepancy in nominal protein contents;

(b) a rate nephelometry method (Array ${ }^{\mathrm{TM}}$ Protein System from Beckman Instruments, Inc., Brea, CA 92621).

\section{Samples}

We used serum and lumbar CSF samples taken from patients, ages 10 to 50 years, who were affected by various neurological diseases. The samples were first stored at $-20^{\circ} \mathrm{C}$, then brought to room temperature, and kept for $30 \mathrm{~min}$ before testing.

Tab. 1. IgG and albumin tests

\begin{tabular}{|c|c|c|c|c|c|c|c|}
\hline & \multicolumn{4}{|l|}{$\mathrm{IgG}$} & \multicolumn{3}{|c|}{ Albumin } \\
\hline & \multicolumn{2}{|l|}{ CSF } & & \multirow[t]{2}{*}{ Serum } & \multirow[t]{2}{*}{ CSF } & & \multirow[t]{2}{*}{ Serum } \\
\hline & $\mathrm{NHR}^{\mathrm{a}}$ ) & $\mathrm{VHR}^{\mathrm{a}}$ ) & & & & & \\
\hline Undiluted sample volume, $\mu$ l & $\begin{array}{l}50 \\
-\end{array}$ & $\overline{5}$ & & $\overline{-}$ & 5 & & - \\
\hline $\begin{array}{l}\text { Diluted }(1: 21) \text { sample volume, } \mu \mathrm{l} \\
\text { IgG antibody reagent volume, } \mu \mathrm{l} \\
\text { Albumin antibody reagent volume, } \mu \mathrm{l} \\
\text { Zeroing } \\
\text { Incubation time, min } \\
\left.\text { Temperature }{ }^{b}\right),{ }^{\circ} \mathrm{C} \\
\left.\text { Wavelength }^{c}\right), \mathrm{nm}\end{array}$ & $\begin{array}{r}- \\
500 \\
-\end{array}$ & $\begin{array}{r}500 \\
-\end{array}$ & $\begin{array}{c}\text { PEG } \\
10 \\
25 \\
340\end{array}$ & $\begin{array}{r}5 \\
500 \\
-\end{array}$ & $\frac{-}{500}$ & $\begin{array}{c}\text { PEG } \\
10 \\
25 \\
340\end{array}$ & $\frac{5}{500}$ \\
\hline $\begin{array}{l}\text { Antigen excess, } \mathrm{mg} / \mathrm{l} \\
\text { Antigen excess, } \mathrm{g} / \mathrm{l}\end{array}$ & 1050 & 10500 & & 220 & 10000 & & 210 \\
\hline
\end{tabular}

a) Up to $440 \mathrm{mg} / \mathrm{l}$ (NHR procedure) and from 70 to $4470 \mathrm{mg} / \mathrm{l}$ (VHR procedure), approximately

b) Also $30^{\circ} \mathrm{C}$ or $37^{\circ} \mathrm{C}$

c) Also $360 \mathrm{~nm}$

All calibration curves using $5 \mu \mathrm{l}$ of working calibrators and $500 \mu \mathrm{l}$ of antibody reagent 
Tab. 2. Working calibrators and typical assay ranges for IgG and albumin tests

\begin{tabular}{|c|c|c|c|c|c|c|c|}
\hline \multirow[b]{3}{*}{$\begin{array}{l}\text { IgG, with } \\
\text { undiluted CSF (NHR), mg/l } \\
\text { diluted CSF (VHR), mg/l } \\
1: 21 \text { diluted serum, g/l }\end{array}$} & \multicolumn{7}{|c|}{ Working calibrators ${ }^{a}$ ), dilutions } \\
\hline & $1: 128$ & $1: 64$ & $1: 12$ & $1: 16$ & $1: 8$ & $1: 4$ & $1: 2$ \\
\hline & $\begin{array}{r}7 \\
70 \\
1.47\end{array}$ & $\begin{array}{r}14 \\
140 \\
2.93\end{array}$ & $\begin{array}{r}28 \\
280 \\
5.87\end{array}$ & $\begin{array}{r}56 \\
560 \\
11.73\end{array}$ & $\begin{array}{r}112 \\
1120 \\
23.47\end{array}$ & $\begin{array}{r}224 \\
2240 \\
46.94\end{array}$ & $\begin{array}{r}447 \\
4470 \\
93.87\end{array}$ \\
\hline & $1: 512$ & $1: 256$ & $1: 128$ & $1: 64$ & $1: 32$ & $1: 16$ & $1: 8$ \\
\hline $\begin{array}{l}\text { Albumin, with } \\
\text { undiluted CSF, mg/1 } \\
1: 21 \text { diluted serum, g/l }\end{array}$ & $\begin{array}{r}68 \\
1.43\end{array}$ & $\begin{array}{r}137 \\
2.88\end{array}$ & $\begin{array}{r}275 \\
5.77\end{array}$ & $\begin{array}{r}550 \\
11.55\end{array}$ & $\begin{array}{r}1100 \\
23.10\end{array}$ & $\begin{array}{r}2200 \\
46.20\end{array}$ & $\begin{array}{r}4400 \\
92.40\end{array}$ \\
\hline
\end{tabular}

a) Prepared from a calibrator containing $8.94 \mathrm{~g} / \mathrm{l} \mathrm{IgG}$ and $35.18 \mathrm{~g} / \mathrm{l}$ albumin. These are typical concentrations; values change with the lot number.

\section{Results}

\section{Reaction kinetics}

The time course of the immunoprecipitation reaction was similar for both IgG and albumin. The formation of insoluble complexes is almost complete after $5 \mathrm{~min}$. Nevertheless we chose a 10 -min reaction time for this "quasi-equilibrium" reaction.

The reaction is not influenced by temperature, and no significant difference was found at $25^{\circ} \mathrm{C}$ and $37^{\circ} \mathrm{C}$.
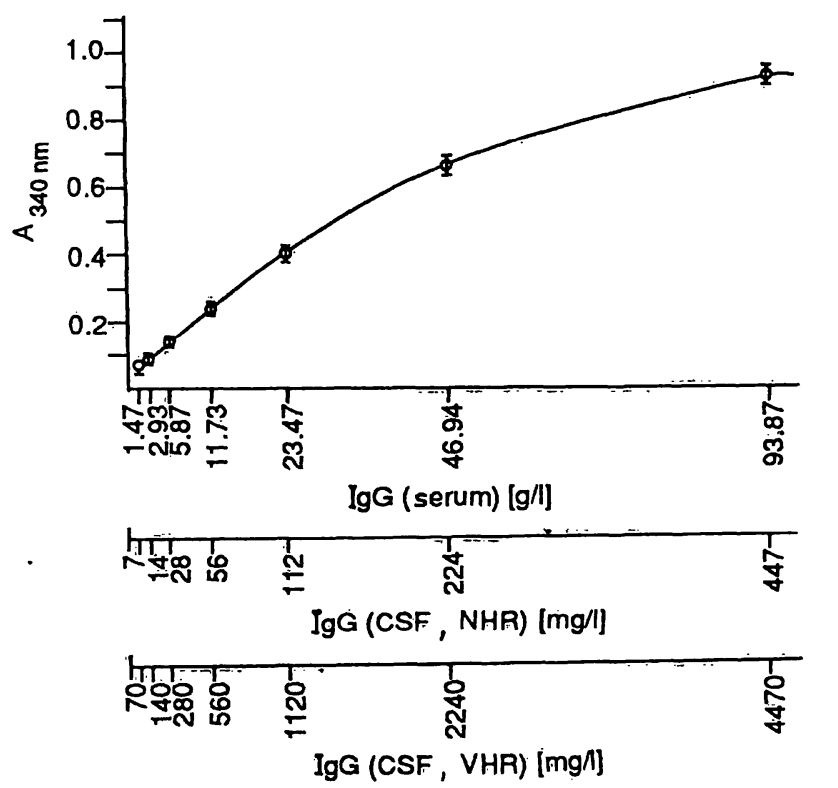

\section{Stability of the calibration curves}

We tested the stability of the calibration curves by assaying the same working calibrators (stored in refrigerator) 8 times in a 30-day period. Figure 1 illustrates the mean calibration curves with the pertinent standard deviations. CVs calculated for each working calibrator are very low: $\leq 3.2 \%$ for IgG and $\leq 2.3 \%$ for albumin.

Fig. 1. Calibration curves for IgG (left) and albumin (right). Mean calibration curves (8 curves over 30 days); bars indicate $\pm 2 S D$

NHR = Normal-High Range procedure

VHR = Very High Range procedure 


\section{Antigen excess}

We evaluated the antigen excess phenomenon by analysing the calibrator supplied and various sera at high protein concentrations. IgG and albumin levels representing antigen excess are given in table 1 , expressed in $\mathrm{mg} / \mathrm{l}$; the actual amount of protein at the equivalence point is $52.5 \mu \mathrm{g}$ IgG per sample and $50 \mu \mathrm{g}$ albumin per sample. If the total protein contents of the samples under examination are known and they are assayed at the proper dilution, falsely low results are unlikely to be obtained.

\section{Precision}

Precision was assessed from 18 replicate assays (6. runs over 15 days) of two serum pools and two CSF samples.
Table 3 shows the results. One of the two CSF samples was tested for IgG with both NHR and VHR procedures. The mean values obtained differ negligibly $(-2.1 \%)$.

\section{Method comparison}

We determined IgG and albumin in 90 routine sera and 90 routine CSF samples in 6 runs over 30 days by the present assay and by RID and rate nephelometry methods. Results were processed by leastsquare regression analysis (8), and statistical param= eters are given in table 4. The results for CSF IgG, obtained by NHR and VHR, were analysed both separately and as a single collection of data.

Tab. 3. Precision data

\begin{tabular}{|c|c|c|c|c|c|c|c|}
\hline \multirow[b]{2}{*}{$\therefore$} & \multirow[t]{2}{*}{ Mean } & \multicolumn{2}{|c|}{ Within-run } & \multicolumn{2}{|c|}{ Between-run } & \multicolumn{2}{|c|}{ Overall } \\
\hline & & $\mathrm{SD}$ & $\mathrm{CV}, \%$ & SD & $\mathrm{CV}, \%$ & SD & $\mathrm{CV}, \%$ \\
\hline \multicolumn{8}{|l|}{ IgG } \\
\hline CSF 1 (NHR), mg/l & 11.5 & 0.10 & 0.87 & 0.32 & 2.78 & 0.33 & 2.87 \\
\hline CSF 2 (NHR), mg/l & 138.8 & 1.23 & 0.89 & 1.34 & 0.96 & 1.82 & 1.31 \\
\hline (VHR), mg/l & 135.9 & 1.31 & 0.96 & 0.12 & 0.09 & 1.32 & 0.97 \\
\hline Serum pool A, g/1 & 10.28 & 0.349 & 3.39 & 0.358 & 3.48 & 0.500 & 4.86 \\
\hline Serum pool B, g/l & 24.15 & 0.405 & 1.68 & 0.216 & 0.89 & 0.459 & 1.90 \\
\hline \multicolumn{8}{|l|}{ Albumin } \\
\hline CSF 1, mg/l & 114.9 & 1.40 & 1.22 & 0.50 & 0.44 & 1.50 & 1.30 \\
\hline $\operatorname{CSF} 2, \mathrm{mg} / 1$ & 695.6 & 7.20 & 1.04 & 5.80 & 0.83 & 9.20 & 1.32 \\
\hline Serum pool A, g/l & 19.56 & 0.134 & 0.68 & 0.136 & 0.69 & 0.191 & 0.98 \\
\hline Serum pool B, g/l & 76.89 & 0.771 & 1.00 & 0.322 & 0.42 & 0.836 & 1.09 \\
\hline
\end{tabular}

$\mathrm{n}=18$ for each determination; over a 15-day period

Tab. 4. Correlation between the immunoturbidimetric method $(y)$ and other methods $(x)$

\begin{tabular}{|c|c|c|c|c|c|c|c|c|c|}
\hline \multirow{2}{*}{$\begin{array}{l}\text { Comparison } \\
\text { methods (x) }\end{array}$} & \multirow[t]{2}{*}{ Sample } & \multirow[t]{2}{*}{$\mathrm{n}$} & \multirow[t]{2}{*}{$\mathbf{r}$} & \multirow[t]{2}{*}{ Slope } & $y$-intercept & $S_{y x}$ & $\overline{\mathbf{x}}$ & $\overline{\mathbf{y}}$ & Range $^{a}$ ) \\
\hline & & & & & \multicolumn{5}{|c|}{$\mathrm{mg} / \mathrm{l}$ for $\mathrm{CSF} ; \mathrm{g} / \mathrm{l}$ for serum } \\
\hline \multicolumn{10}{|l|}{$\operatorname{IgG}$} \\
\hline \multirow[t]{2}{*}{ RID } & CSF & $\left.90^{b}\right)$ & 0.965 & 1.003 & 1.1 & 29.9 & 97.7 & 99.0 & $7-1000$ \\
\hline & Serum & 90 & 0.955 & 0.908 & 0.68 & 0.10 & 12.63 & 12.15 & $5.65-26.50$ \\
\hline \multirow[t]{2}{*}{$\begin{array}{l}\text { Rate } \\
\text { nephelometry }\end{array}$} & $\begin{array}{l}\text { CSF } \\
\text { CSF } \\
\text { CSF }\end{array}$ & $\begin{array}{l}\left.81^{c}\right) \\
\left.25^{d}\right) \\
\left.90^{b}\right)\end{array}$ & $\begin{array}{l}0.998 \\
0.999 \\
0.999\end{array}$ & $\begin{array}{l}1.043 \\
1.036 \\
1.042\end{array}$ & $\begin{array}{r}-1.3 \\
1.6 \\
-1.0\end{array}$ & $\begin{array}{l}4.5 \\
8.1 \\
5.9\end{array}$ & $\begin{array}{r}58.6 \\
249.1 \\
96.0\end{array}$ & $\begin{array}{r}59.8 \\
259.7 \\
99.0\end{array}$ & $\begin{array}{r}7-330 \\
69-1100 \\
7-1100\end{array}$ \\
\hline & Serum & 90 & 0.967 & 1.073 & -0.35 & 0.39 & 11.67 & 12.17 & $5.65-26.50$ \\
\hline \multicolumn{10}{|l|}{ Albumin } \\
\hline \multirow[t]{2}{*}{ RID } & CSF & 90 & 0.987 & 0.982 & -2.8 & 43.2 & 411.0 & 401.0 & $32-3630$ \\
\hline & Serum & 90 & 0.976 & 0.986 & -0.42 & 1.98 & 42.10 & 41.09 & $27-84.35$ \\
\hline \multirow{2}{*}{$\begin{array}{l}\text { Rate } \\
\text { nephelometry }\end{array}$} & CSF & 90 & 0.999 & 1.080 & -8.2 & 27.9 & 379.1 & 401.2 & $32-3630$ \\
\hline & Serum & 90 & 0.982 & 1.012 & 0.27 & 1.42 & 40.32 & 41.08 & $27-84.35$ \\
\hline
\end{tabular}




\section{Interferences}

We explored the effect of haemoglobin, bilirubin, and triacylglycerols on the test results.

The high predilution of serum samples $(1: 21)$ minimizes the potential interference by elevated concentrations of such substances. IgG and albumin results were only slightly overestimated (by less than 9.5 and $10.2 \%$ ) in three normal sera spiked with haemoglobin $(8000 \mathrm{mg} / \mathrm{l})$, bilirubin $(50 \mathrm{mg} / \mathrm{l})$, and triacylglycerols $(4000 \mathrm{mg} / \mathrm{l})$. Although CSF samples are analysed undiluted, potential interference is very low. Nevertheless, a sample blank should be run for samples with a high level of bilirubin (an unusual occurrence) or haemoglobin (subarachnoid haemorrhages, CSF withdrawal contaminated with blood). IgG and albumin results were in fact overestimated by about $25 \%$ and $30 \%$ in a sample with $500 \mathrm{mg} / \mathrm{l}$ of haemoglobin.

We also tested the effect of the most widely used anticoagulants. No significant interference was found for sodium heparin, sodium citrate, or disodium EDTA up to four times the commonly used concentrations.

\section{Carry-over}

\section{Two CSF pools}

1) albumin $3050 \mathrm{mg} / \mathrm{l}$ and $\mathrm{IgG} 580 \mathrm{mg} / \mathrm{l}$;

2) albumin $128 \mathrm{mg} / \mathrm{l}$ and $\mathrm{IgG} 18 \mathrm{mg} / \mathrm{l}$

and two serum pools

1) albumin $72 \mathrm{~g} / \mathrm{l}$ and IgG $45 \mathrm{~g} / \mathrm{l}$;

2) albumin $22 \mathrm{~g} / 1$ and $\mathrm{IgG} 5.2 \mathrm{~g} / \mathrm{l}$

were analysed in the sequence:

1-1-1-2-2-2-1-1-1-2-2-2.

Average carry-over was $4.2 \%$ (CSF) and $7.3 \%$ (serum) for IgG, and 5.0\% (CSF) and $8.5 \%$ (serum) for albumin.

\section{Discussion}

We found that the present method for the immunoturbidimetric quantitation of $\mathrm{IgG}$ and albumin in CSF and serum (or plasma) gives good results and is convenient to perform.
Calibration curves are stable, precision is very good, and the accuracy, compared with that of other widely used methods, is certainly satisfactory. Interestingly, the same calibration curve can be used both for CSF and serum samples despite their remarkably different protein concentrations. The sensitivity of the CSF IgG assay $(6 \mathrm{mg} / \mathrm{l})$ is high, and superior to that of immunonephelometry $(12 \mathrm{mg} / \mathrm{l})$.

Dilution of polyethylene glycol, the enhancer of the immunoprecipitation reaction, by the larger amount of CSF sample in the NHR procedure $(50 \mu l$ instead of $5 \mu \mathrm{l}$ ) does not significantly influence the reaction kinetics, as shown by the equivalent results from the NHR and VHR procedures (tabs. 3 and 4). From a practical point of view, favourable features of the method are the use of the same predilution $(1: 21)$ of serum samples for both proteins, and the adaptability both to a plain spectrophotometer and to common automated analysers.

The level of interference from haemoglobin, bilirubin, and triacylglycerols is generally acceptable, but strongly haemolysed CSF samples should be run with a sample blank for higher accuracy. Dose response curves for immunoturbidimetric assays are non-linear (fig. 1). Basically, there are two computing algorithms for describing adequately these curves and both require a computerized program to process and store the curves. We obtained the best fit with the fourparameter logistic model; equivalent results can also be obtained with a third-order polynomial function, although it sometimes yields minor mathematical artefacts, such as flexures between the two highest working calibrators. To obtain analytically reliable values, it is worthwhile underlining the importance of measuring all the terms of the various ratios and formulae mentioned in the Introduction with the same assay method.

In summary, the immunoturbidimetric method described here proved to be simple, rapid, easy to use, and accurate in measuring $\operatorname{IgG}$ and albumin in CSF and serum samples. Both small and large batches of specimens can be analysed with equal convenience. The method is therefore useful for all laboratories involved in the assay of CSF proteins.

\section{References}

1. Lowenthal, A., van Sande, M. \& Karcher, D. (1960) The differential diagnosis of neurological disease by fractioning electrophoretically the CSF gamma globulins. J. Neurochem. $6,51-56$ :

2. Link, H. (1967) Immunoglobulin $G$ and low molecular weight proteins in human cerebrospinal fluid: chemical and immunological characterization with special reference to multiple sclerosis. Acta Neurol. Scand. 43, 1-136 (suppl. 28). 
3. Tibbling, G., Link, H. \& Ohman, S. (1977) Principles of albumin and IgG analysis in neurological disorders. I. Establishment of reference values. Scand. J. Clin. Lab. Invest. $37,385-390$.

4. Tourtelotte, W. W., Ma, B. I. \& Brandes, D. B. (1981) Quantification of de novo central nervous system IgG measles antibody synthesis in SSPE. Ann. Neurol. 9, 551 - 556.

5. Reiber, H. \& Felgenhauer, K. (1987) Protein transfer at the blood cerebrospinal fluid barrier and the quantitation of the humoral immune response within the central nervous system. Clin. Chim. Acta 163, 319-328.
6. Donà, V., Papagni, M., Tarenghi, G., Aguzzi, F. \& Berti, G. (1987) Specific serum protein quantitation by a simple immunoturbidimetric method. Giorn. It. Chim. Clin. 12, 205214.

7. Reimer, C. B., Smith, J. S., Wells, T. W., Nakamura, R. M., Keitges, P. W., Ritchie, R. F., Williams, G. W., Hanson, D. J. \& Dorsey, D. B. (1982) Collaborative calibration of the U.S. National and the College of American Pathologists reference preparations for specific ; serum proteins. Am. J. Clin. Pathol. 77, 12-19.

8. Westgard, J. O. \& Hunt, R. M. (1973) Use and interpretation of common statistical tests in method-comparison studies. Clin. Chem. 19, 49-57.

Dr. Danilo Croci

Istituto Neurologico "C. Besta"

Via Celoria 11

I-20133 Milano 